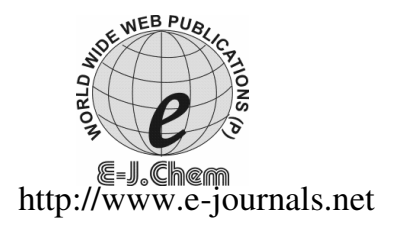

\author{
ISSN: 0973-4945; CODEN ECJHAO \\ E-Journal of Chemistry \\ 2011, 8(4), 1958-1964
}

\title{
RP-HPLC Determination of Atomoxetine Hydrochloride in Bulk and Pharmaceutical Formulations
}

\author{
H. R. PRAJAPATI", P. N. RAVESHIYA and J M. PRAJAPATI \\ Department of Pharmaceutical Chemistry \\ A. R. College of Pharmacy \\ Vallabh Vidyanagar-388 120, Gujarat, India \\ hetal_arcp@yahoo.co.in
}

Received 19 December 2010; Accepted 28 February 2011

\begin{abstract}
A reversed phase high performance liquid chromatographic (RP-HPLC) method was developed and subsequently validated for the determination of atomoxetine hydrochloride in bulk and pharmaceutical formulation. The separation was done by a PerkinElmer Brownlee analytical

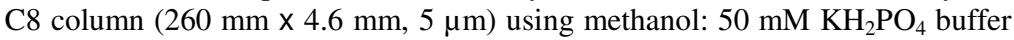
( $\mathrm{PH}$ adjusted to 6.8 with $0.1 \mathrm{M} \mathrm{NaOH}$ ), $80: 20 \mathrm{v} / \mathrm{v}$ as an eluent. UV detection was performed at $270 \mathrm{~nm}$ at a flow rate $1.0 \mathrm{~mL} / \mathrm{min}$. The validation of the method was performed, and specificity, reproducibility, precision accuracy and ruggedness were confirmed. The correlation coefficient was found to be 0.997 for atomoxetine hydrochloride. The recovery was in the range of 99.94 to $100.98 \%$ and limit of quantification was found to be $5.707 \mu \mathrm{g} / \mathrm{mL}$. The method is simple, rapid, selective and economical too and can be used for the routine analysis of drug in pharmaceutical formulations.
\end{abstract}

Keywords: Atomoxetine hydrochloride, RP-HPLC, Validation

\section{Introduction}

Atomoxetine is the first non-stimulant drug approved for the treatment of an attention-deficit hyperactivity disorder (ADHD). It is sold in the form of the hydrochloride salt of atomoxetine. It is a selective nor-adrenaline reuptake inhibitor ${ }^{1,2}$. Chemically, it is (R)n-methyl-3-(2-methylphenoxy)-3-phenylpropylamine ${ }^{3}$. It is not official in any pharmacopoeias. Literature survey reveals that several methods have been reported like HPLC, HPLC-MS and HPTLC for its estimation in plasma and in capsule dosage form ${ }^{3-7}$. The present work reports simple, rapid, sensitive and economical RP-HPLC method with UV detection, useful for the routine analysis of atomoxetine hydrochloride in bulk and pharmaceutical 
formulations. The method was validated by parameters such as linearity, accuracy, precision, robustness, stability and system suitability as per ICH guidelines and USP requirements ${ }^{8,9}$. Suitable statistical tests were performed on validation data ${ }^{10,11}$. The structure of atomoxetine hydrochloride ${ }^{3}$ is given in Figure 1.<smiles>CCCCCCCc1ccccc1OC(CCNC)c1ccccc1</smiles>

\section{Experimental}

Figure 1. Structure of atomoxetine hydrochloride

HPLC system is used for this study, the specifications are given below. Quantitative HPLC was performed on a isocratic high pressure liquid chromatography (PerkinElmer series-2000) equipped with a series 200 LC pump, 200 UV-VIS LC detector (Dual channel), Rhenodyne valve (model 7725i) with $20 \mu \mathrm{L}$ fixed loop injector, PerkinElmer Brownlee analytical C8 column (260 mm x $4.6 \mathrm{~mm}, 5 \mu \mathrm{m})$ and a software TotalChrom Workstation (version 6.3.1).

\section{Reagents and chemicals}

HPLC grade methanol and triple distilled water were procured from Lichrosolv-E. Merck (India) Ltd., Mumbai. Sodium hydroxide (A. R. grade) and potassium dihydrogen orthophosphate (A. R. grade) were obtained from allied chemical corporation, vadodara. Pure sample of drug was received as gift sun pharmaceuticals Pvt. Ltd., vadodara. Atomoxetine tablets (Axepta-40 mg) and capsules (Attentrol-25 mg) were procured from Intas Pharmaceutical Pvt. Ltd and sun pharmaceutical Pvt, Ltd., vadodara respectively. Triple distilled water was used to prepare all the solutions required for the method.

\section{Preparation of buffer}

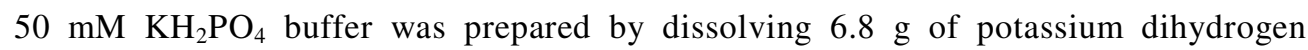
ortho- phosphate in $1000 \mathrm{~mL}$ of triple distilled water and $\mathrm{pH}$ was adjusted to 6.8 with $0.1 \mathrm{M} \mathrm{NaOH}$.

\section{Preparation of atomoxetine hydrochloride $(100 \mu \mathrm{g} / \mathrm{mL})$ standard stock solution}

A $50 \mathrm{mg}$ of standard atomoxetine hydrochloride was accurately weighed and transferred to a $50 \mathrm{~mL}$ volumetric flask. It was dissolved in $30 \mathrm{~mL}$ mobile phase. The flask was sonicated for $10 \mathrm{~min}$. The flask was shaken and volume was made up to the mark with mobile phase to give a solution containing $1000 \mu \mathrm{g} / \mathrm{mL}$ atomoxetine hydrochloride. From this solution, $2.5 \mathrm{~mL}$ was transferred to $25 \mathrm{~mL}$ volumetric flask. The volume was adjusted up to the mark with the mobile phase to give a solution containing $100 \mu \mathrm{g} / \mathrm{mL}$ atomoxetine hydrochloride.

\section{Determination of atomoxetine hydrochloride in pharmaceutical formulations}

Sample preparation of atomoxetine hydrochloride in tablet dosage form

Twenty tablets were weighed and powdered. Powder equivalent to $25 \mathrm{mg}$ of atomoxetine was transferred to $50 \mathrm{~mL}$ of volumetric flask containing $30 \mathrm{~mL}$ of mobile phase and sonicated for $10 \mathrm{~min}$. The flask was shaken and volume was made up to the mark with mobile phase. 
The flask was shaken and volume was made up to the mark with mobile phase to give a solution containing $500 \mu \mathrm{g} / \mathrm{mL}$ atomoxetine Hydrochloride. The resulting solution was filtered through a $0.45 \mu \mathrm{m}$ membrane filter. $2 \mathrm{~mL}$ of aliquot was taken and transferred to volumetric flask of $10 \mathrm{~mL}$ capacity and volume was made up to the mark with the mobile phase to give a solution containing $100 \mu \mathrm{g} / \mathrm{mL}$ atomoxetine hydrochloride. From the above solution $2.5 \mathrm{~mL}$ of aliquot was taken and transferred to volumetric flask of $10 \mathrm{~mL}$ capacity and volume was made up to the mark with the mobile phase to give a solution containing $25 \mu \mathrm{g} / \mathrm{mL}$ atomoxetine hydrochloride. This solution was used for the estimation of atomoxetine.

\section{Sample preparation of atomoxetine hydrochloride in capsule dosage form}

Twenty capsules were opened. Powder was taken and weighed. Sample solution was prepared as per the procedure described for sample preparation of amotoxetine hydrochloride tablet.

\section{Chromatographic conditions}

The contents of mobile phase were a mixture of methanol and $50 \mathrm{mM} \mathrm{KH}_{2} \mathrm{PO}_{4}$ buffer (pH adjusted to 6.8 with $0.1 \mathrm{M} \mathrm{NaOH}$ ) in the ratio of 80:20v/v. It was filtered through $0.45 \mu \mathrm{m}$ filter paper, sonicated for 10 minutes to degas the mixture. The flow rate of the mobile phase was maintained at $1.0 \mathrm{~mL} / \mathrm{min}$. The column temperature was set at $25 \pm 1{ }^{\circ} \mathrm{C}$ and the detection was carried out by UV-Detector at a $226 \mathrm{~nm}$ wave length. The run time was set at 10 minutes and the volume of injection loop was $20 \mu \mathrm{L}$. Prior to the injection of the drug solution, the column was equilibrated for at least 30 minutes with the mobile phase flowing through the system. The data were acquired, stored and analysed with the software TotalChrom Workstation (version 6.3.1).

\section{Calibration procedure}

The calibration curve was plotted with five different concentrations $(10-50 \mu \mathrm{g} / \mathrm{mL})$ of the standard drug solution. Before injecting the solutions, the column was equilibrated for at least 30 minutes with the mobile phase flowing through the system. Six determinations were carried out for each dilution and graph was plotted for mean peak area response versus concentration of the drug. The linearity was evaluated by linear regression analysis.

\section{Results and Discussion}

The applied chromatographic conditions permitted a good resolution of atomoxetine hydrochloride in standard solution (A) and in sample solution for tablet (B) and capsule (C) (Figure 2). No drug decomposition was observed during the analysis. The HPLC method was validation for the parameters reported below.

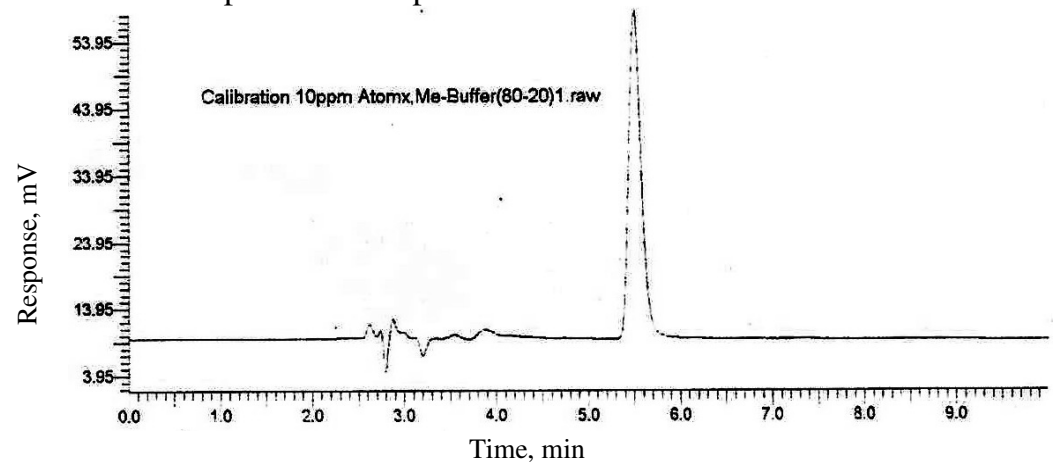

Figure 2. (A) Chromatogram of standard solution containing $10 \mu \mathrm{g} / \mathrm{mL}$ atomoxetine hydrochloride using mobile phase methanol: $50 \mathrm{mM} \mathrm{KH}_{2} \mathrm{PO}_{4}$ buffer $(\mathrm{pH}=6.8), 80: 20 \% \mathrm{v} / \mathrm{v}$ (Proposed Method). 


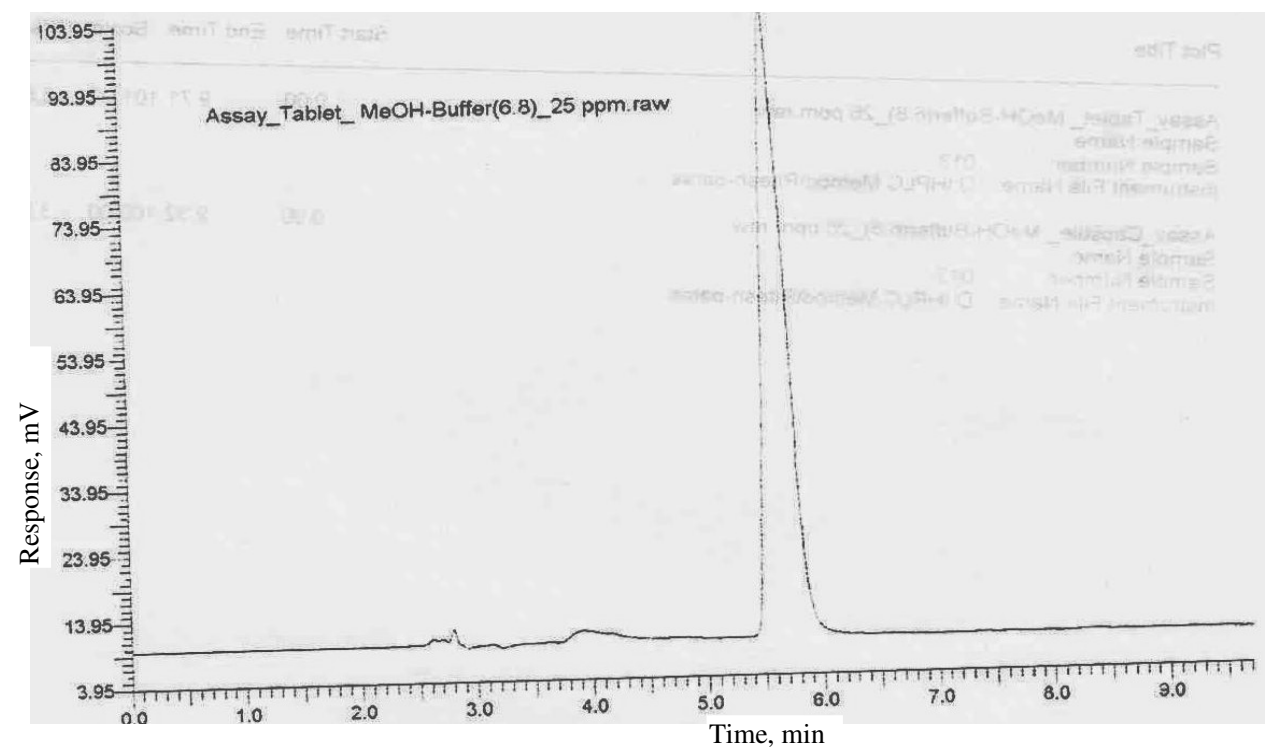

Figure 2. (B) Chromatogram of sample (tablet) solution containing $25 \mu \mathrm{g} / \mathrm{mL}$ atomoxetine hydrochloride using mobile phase methanol: $50 \mathrm{mM} \mathrm{KH}_{2} \mathrm{PO}_{4}$ buffer $(\mathrm{pH}=6.8), 80: 20 \% \mathrm{v} / \mathrm{v}$.

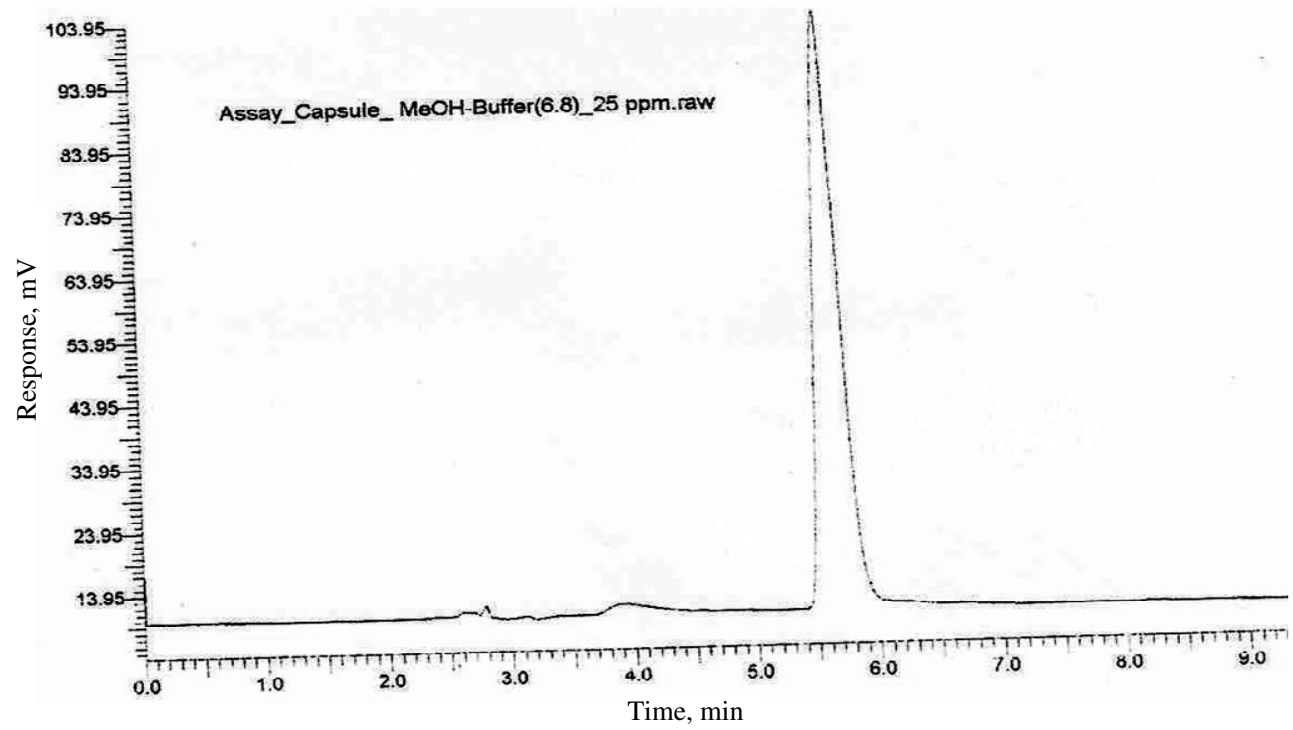

Figure 2. (C) Chromatogram of sample (capsule) solution containing $25 \mu \mathrm{g} / \mathrm{mL}$ atomoxetine hydrochloride using mobile phase methanol : $50 \mathrm{mM} \mathrm{KH}_{2} \mathrm{PO}_{4}$ buffer $(\mathrm{pH}=$ $6.8), 80: 20 \% \mathrm{v} / \mathrm{v}$.

\section{Linearity}

The atomoxetine hydrochloride was chromatographed using the mobile phase and the linearity of peak area response versus concentration was studied from $10-50 \mu \mathrm{g} / \mathrm{mL}$. A linear response was observed over the examined concentration range. The results are tabulated in the Table 1. 
Table 1. Results of the data analysis for the quantitative determination of atomoxetine hydrochloride by RP-HPLC method

\begin{tabular}{ll}
\hline Statistical parameters & Atomoxetine hydrochloride \\
\hline Linear range, $\mu \mathrm{g} / \mathrm{mL}$ & $10-50$ \\
Regression equation & $\mathrm{Y}=198625 \mathrm{X}+136739$ \\
Correlation coefficient $(\mathrm{r})$ & 0.997 \\
Limit of detection (LOD), $\mu \mathrm{g} / \mathrm{mL}$ & 1.883
\end{tabular}

\section{Accuracy}

The accuracy of the RP-HPLC method was assessed by adding a known amount $(12.5,25.0$, and $37.5 \mu \mathrm{g} / \mathrm{mL})$ of drug to a drug solution of known concentration $(25 \mu \mathrm{g} / \mathrm{mL})$ and subjecting the samples to the proposed method. The known amount of drug $(12.5,25.0$ and $37.5 \mu \mathrm{g} / \mathrm{mL}$ ) was also added to sample solutions of tablet and capsule, each containing $25 \mu \mathrm{g} / \mathrm{mL}$ atomoxetine hydrochloride. The drug was estimated as the procedure described for the estimation of atomoxetine hydrochloride in the tablet and capsule formulations. In all the cases the recovery studies were replicated five times. The accuracy was expressed in terms of the recovery and calculated by multiplying the ratio of measured drug concentration with 100, so as to give the percentage recovery (Table 2 and 3).

Table 2. Recovery of the atomoxetine hydrochloride in tablet dosage form using proposed method.

\begin{tabular}{ccc}
\hline Amount of drug added, $\mu \mathrm{g} / \mathrm{mL}$ & Amount recovered, $\mu \mathrm{g} / \mathrm{mL}, \mathrm{n}=5$ & \% Recovery, $\mathrm{n}=5$ \\
\hline 12.5 & 37.77 & 100.72 \\
25.0 & 50.49 & 100.98 \\
37.5 & 62.87 & 100.59 \\
\hline
\end{tabular}

Table 3. Recovery of atomoxetine hydrochloride in capsule dosage form using proposed method.

\begin{tabular}{ccc}
\hline Amount of drug added, $\mu \mathrm{g} / \mathrm{mL}$ & Amount recovered, $\mu \mathrm{g} / \mathrm{mL}, \mathrm{n}=5$ & \% Recovery, $\mathrm{n}=5$ \\
\hline 12.5 & 37.61 & 100.29 \\
25.0 & 49.97 & 99.44 \\
37.5 & 62.66 & 100.25 \\
\hline
\end{tabular}

The method was found to be accurate with percentage recovery $100.59-100.98 \%$ and 99.94-100.29\% for atomoxetine hydrochloride tablet and capsule respectively.

\section{Precision}

The precision of the assay was determined in terms of intra and inter day variation in the peak area for a set of drug solution $(20,30$ and $40 \mu \mathrm{g} / \mathrm{mL})$ assayed three times on the same day (intraday) and on three different days (interday). The intraday and interday variation in the peak ratio of the drug solution was calculated in terms of \% RSD (Table 4).

Table 4. Interday and intraday precision for atomoxetine hydrochloride

\begin{tabular}{ccccc}
\hline \multirow{2}{*}{$\begin{array}{c}\text { Atomoxetine } \\
\text { hydrochloride }\end{array}$} & \multicolumn{2}{c}{ Concentration of atomoxetine hydrochloride $(\mu \mathrm{g} / \mathrm{mL})$ found on- } \\
\cline { 2 - 5 } concentration, $\mu \mathrm{g} / \mathrm{mL}$ & Mean area, $\mathrm{n}=3$ & \% RSD & Mean area, $\mathrm{n}=3$ & \% RSD \\
\cline { 2 - 5 } 20 & $695277.3 \pm 2738.8$ & 0.3939 & $694119.8 \pm 1641.1$ & 0.2364 \\
30 & $1155453 \pm 1379.82$ & 0.1194 & $1154234 \pm 1295.5$ & 0.1122 \\
40 & $1504489 \pm 2658.26$ & 0.1766 & $1504140 \pm 3751.7$ & 0.2494 \\
\hline
\end{tabular}


The method was found to be precise with \% RSD 0.11- 0.39 for inter-day $(\mathrm{n}=3)$ and $\%$ RSD 0.11- 0.24 for intraday $(n=3)$ for atomoxetine hydrochloride. The method was found to be reproducible. The method was found to be specific as no interference observed when the drug was estimated in presence of excipients.

\section{Robustness}

As defined by the $\mathrm{ICH}$, the robustness of an analytical procedure describes to its capability to remain unaffected by small and deliberate variations in method parameters. Robustness was performed by small variation in the chromatographic conditions and found to be unaffected by small variations like $\pm 2 \%$ variation in volume of mobile phase composition, $\pm 0.1 \mathrm{~mL} / \mathrm{min}$ variation in flow rate of mobile phase and \pm 0.1 variation in $\mathrm{pH}$.

\section{Limit of detection and limit of quantification}

The parameters LOD and LOQ were determined on the basis of signal to noise ratio. LOD and LOQ were calculated by the method which was based on the standard deviation of the response and the slope (S) of the calibration curve and found to be 1.883 and $5.707 \mu \mathrm{g} / \mathrm{mL}$ respectively (Table 1 ).

\section{Ruggedness}

The method was also found to be rugged as there was no change in absorbance up to $48 \mathrm{~h}$ of preparation of solution in methanol.

\section{Reproducibility}

The method was found to be reproducible as there was no significant difference when sample concentration $(25 \mu \mathrm{g} / \mathrm{mL})$ was estimated using two different instruments, result of $t$-test obtained was $1.74(<4.30)$ (Table 5).

Table 5. Reproducibility data for atomoxetine hydrochloride $(25 \mu \mathrm{g} / \mathrm{mL})$

\begin{tabular}{cccc}
\hline $\begin{array}{c}\text { Instrument } 1 \\
\text { Peak area } \pm \text { S.D }(n=3)\end{array}$ & $\begin{array}{c}\text { Instrument } 2 \\
\text { Peak area } \pm \text { S.D }(n=3)\end{array}$ & Result of t-test & Inference \\
\hline $902084.06 \pm 1062.06$ & $907530.83 \pm 886.98$ & 1.74 & $\begin{array}{c}\text { No significant } \\
\text { difference }\end{array}$ \\
\hline
\end{tabular}

Repeatability

*At $95 \%$ confidence interval, $(t$-Tabulated $=4.3)$

The repeatability for atomoxetine hydrochloride was determined by taking atomoxetine hydrochloride sample (tablet) solution $(25 \mu \mathrm{g} / \mathrm{mL})$, assayed six times $(\mathrm{n}=6)$ and RSD was found to be 0.0036 (Table 6).

Table 6. Repeatability of atomoxetine hydrochloride sample (tablet) solution $(25 \mu \mathrm{g} / \mathrm{mL})$

\begin{tabular}{lc}
\hline Concentration of atomoxetine hydrochoride solution & $25 \mu \mathrm{g} / \mathrm{mL}$ \\
\hline Mean Peak Area & 901079.1 \\
Std. Dev. & 33.17 \\
RSD & 0.0036 \\
\hline
\end{tabular}

Assay for marketed dosage forms i.e. tablet and capsule was also performed (Table 7). The tablet (Axepta) and capsule (Attentrol) were found to contain $98.99 \%$ and $100.45 \%$ of the labelled amount respectively. 
Table 7. Assay results of marketed dosage forms

\begin{tabular}{cccc}
\hline Formulations & $\begin{array}{c}\text { Actual concentration } \\
\mu \mathrm{g} / \mathrm{mL}\end{array}$ & $\begin{array}{c}\text { Amount obtained } \\
\mu \mathrm{g} / \mathrm{mL}\end{array}$ & $\%$ purity \\
\hline Tablet (Axepta) & 25 & 24.69 & 98.99 \\
Capsule (Attentrol) & 25 & 25.33 & 100.45 \\
\hline
\end{tabular}

\section{Conclusion}

The proposed reversed phase high performance liquid chromatography method has been evaluated over the linearity, precision, accuracy, reproducibility, robustness, ruggedness and proved to be convenient and effective for the routine analysis of atomoxetine hydrochloride in pharmaceutical formulations. The measured signal was shown to be precise, accurate and linear over the concentration range tested $(10-50 \mu \mathrm{g} / \mathrm{mL})$ with a correction coefficient of 0.997 . The recovery was in the range of $99.94-100.98 \%$ for atomoxetine hydrochloride. Limit of quantification for atomoxetine hydrochloride was found to be $5.707 \mu \mathrm{g} / \mathrm{mL}$. Thus, the proposed method is simple, rapid, accurate, selective, repeatable and requires simple sample preparation procedure. Moreover, an utilisation of methanol: buffer (80: 20) as a mobile phase makes this method cost effective.

\section{Acknowledgment}

The authors are grateful to the Principal, A. R. College of Pharmacy and G. H. Patel Institute of Pharmacy, Vallabh Vidyanagar and the Director, Sophisticated Instrumentation Centre for Applied Research and Testing (SICART), Vallabh Vidyanagar for the support and providing research facilities. Authors are thankful to University Grants Commission, New Delhi for funding this research project.

\section{References}

1. Spencer T J, Faraone S V and Michelson D, Adler L A, Reimherr F W, Glatt S J and Biederman, J Clin Psychiatry, 2006, 67(3), 415-420.

2. Prasad S and Steer C, Paediatric Drugs, 2008, 10(1), 39-47.

3. Patel C, Patel M and Rani S, Nivsarkar M and Padh H, J Chromatogr B, 2007, 850, 356-360.

4. Wei G, Wenbiao L, Guixin G, Jun Z, Beilei Z, Yimin Z and Chuanyue W J, Chromatogr Analyt Technol Biomed Life Sci., B 2007, 854, 128-134

5. Gavin P F and Olsen B A, J Pharm Biomed Anal., 2008, 46(3), 431-441.

6. Mullen J H, Shugert R L ,Ponsler G D, Li Q, Sundaram B, Coales H L, Yakupkovic J E, LeLacheur R M, Wheeler W J, Belas F J and Sauer J M, J Pharm Biomed Anal., 2005, 38(4), 720-733.

7. Hemalata K and Satyanarayana D, Asian J Chem., 2008, 20(7), 54-57.

8. The European Agency for the Evaluation of Medical/Products, ICH Topic Q2BNote for Guideline on Validation of Analytical Procedures, Methodology GPMP/ICH/281/ 95, 1996.

9. United States Pharmacopoeia, Validation of Compendial Methods, $26^{\text {th }}$ Ed., Pharmacopoeial Convention Inc., Rockville, MD, 2003, 2439-2442.

10. Bolton S, Pharmaceutical Statistics: Practical and Clinical application, $3^{\text {rd }}$ Ed., Marcel Dekker, New York, 1997, 216-264.

11. Miller J C and Miller J N, Statistics for Analytical Chemistry, $2^{\text {nd }}$ Ed., Wiley, New York, 1984, 83-117. 


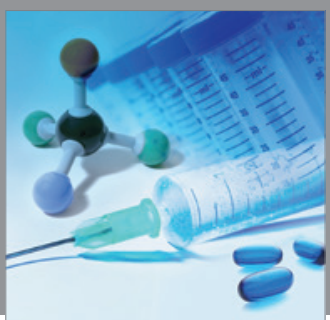

International Journal of

Medicinal Chemistry

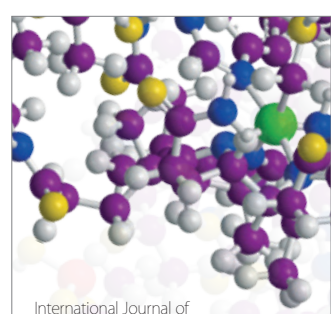

Carbohydrate Chemistry

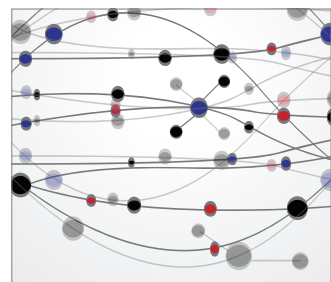

The Scientific World Journal
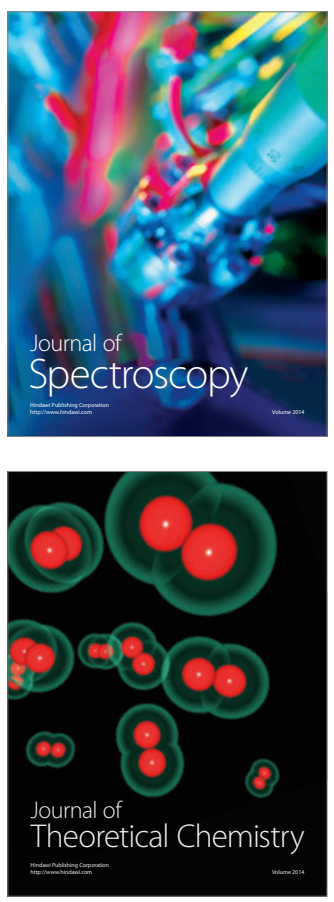
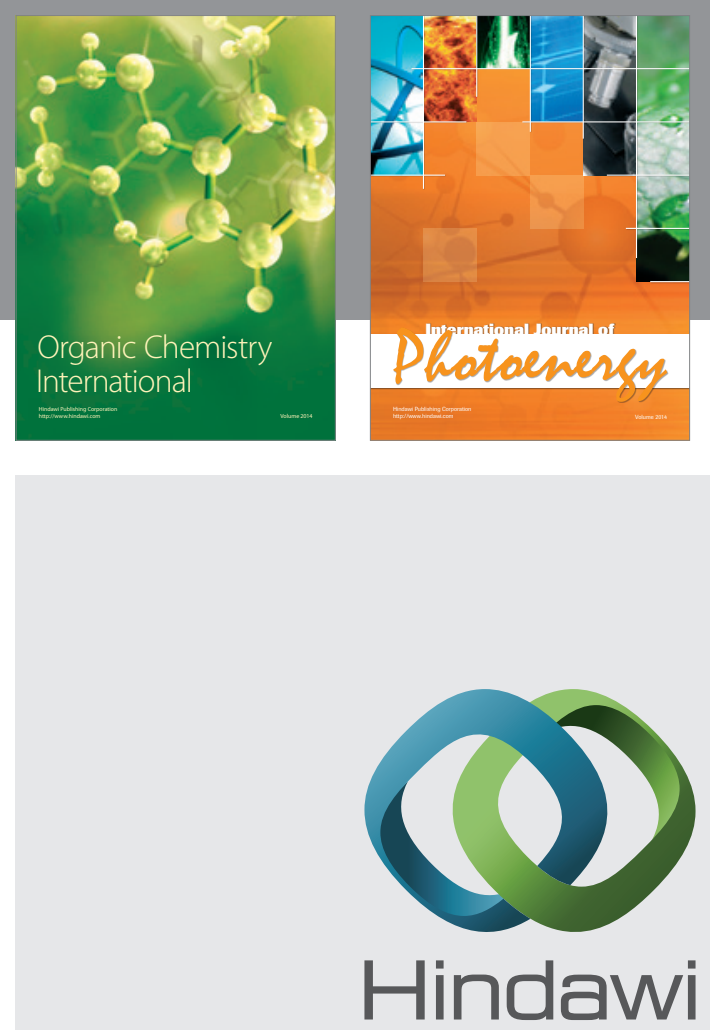

Submit your manuscripts at

http://www.hindawi.com
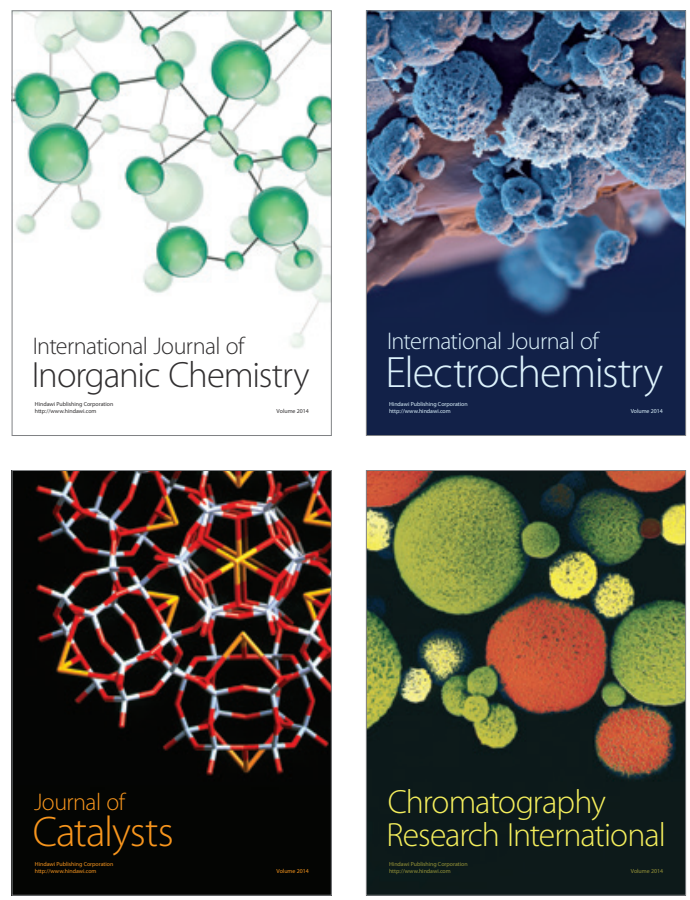
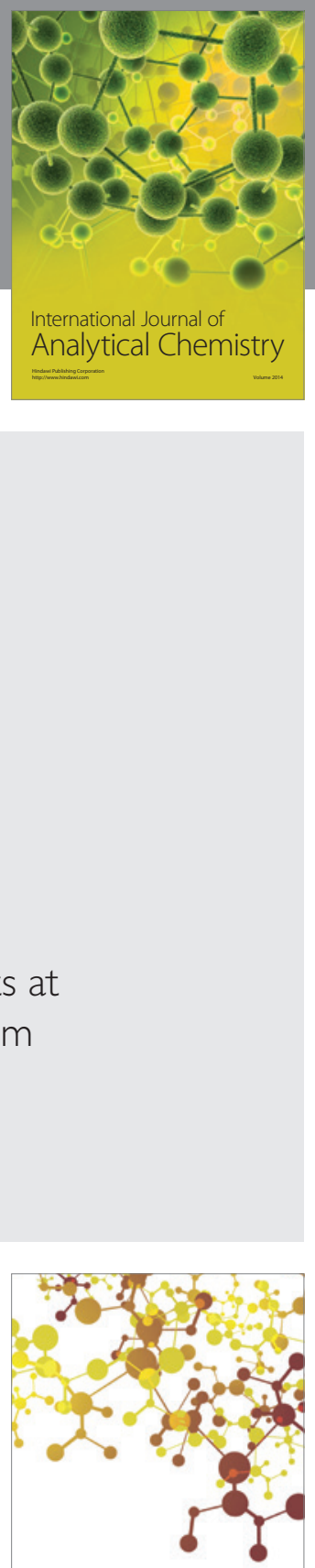

Journal of

Applied Chemistry
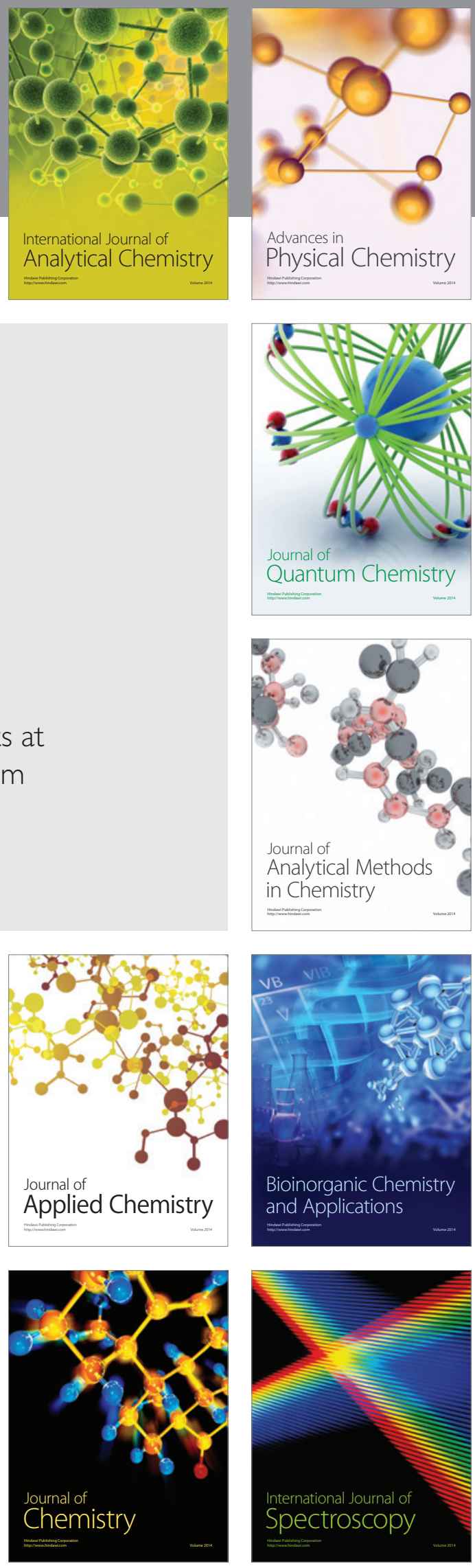